\title{
Age and growth of blackfin tuna (Thunnus atlanticus) caught under moored fish aggregating devices, around Martinique Island
}

\author{
Mathieu Doray ${ }^{1, a}$, Bernard Stéquert $^{2}$ and Marc Taquet ${ }^{3}$ \\ ${ }^{1}$ Laboratoire Ressources halieutiques, Station IFREMER Antilles, 97231 Le Robert, Martinique, France \\ 2 Laboratoire de Sclérochronologie des animaux aquatiques, IRD Bretagne, BP 70, 29280 Plouzané, France \\ ${ }^{3}$ Laboratoire Ressources halieutiques, Station IFREMER de la Réunion, BP 60, 97822 Le Port Cedex, La Réunion, France
}

Received 23 May 2003; Accepted 15 December 2003

\begin{abstract}
Daily growth increments measured in the otolith of Thunnus atlanticus were used to estimate the age and growth of individuals, which were sampled from an artisanal fishery operating around fish aggregating devices (FADs) moored off Martinique Island. In this study, 76 otoliths were analysed for fish ranging from 20 to $68 \mathrm{~cm}$ fork lengths $(F L)$. The fish were caught using trolling lines at depths ranging from 0 to $10 \mathrm{~m}$. Counts were made, under a light microscope, on the external part of the transverse section of the sagittae, from the primordium to the ventral edge. The mean coefficient of variation of the age reading was $2.4 \%$. To validate readings, the number of increments for 11 individuals was counted using both optic and scanning electron microscopes. The calculated relationship between readings of both methods was found to be linear, with a slope of 1.03 and $R^{2}=0.99$. Frequency of growth increment formation could not be validated. Growth rates derived from otolith readings were, however, compared to those obtained using a modal progression analysis, which was performed on the length-frequency distributions of the landings over a period of two months. The corroboration between the growth rates was good. One increment was assumed to represent one day. The parameters of the von Bertalanffy growth curve for both sexes were $L_{\infty}=71.4 \mathrm{~cm} \mathrm{FL,} k=0.002$ day $^{-1}$ and $t_{0}=-80$ days. According to our results, there is no evidence that Martinican moored FADs act as ecological traps for blackfin tuna. Instead, young blackfin tuna probably leave the vicinity of Martinican moored FADs to undergo a trophic migration at 7 to 8 month-old, and then come back about 8 months later to breed in the Lesser Antilles area.
\end{abstract}

Key words: Age / Otolith / Daily increment / Thunnus atlanticus

\begin{abstract}
Résumé - Les microstructures présentes dans les otolithes de Thunnus atlanticus ont été utilisées pour estimer l'âge et la croissance des thons capturés par la pêcherie artisanale exploitant les dispositifs de concentrations de poissons (DCP) mouillés autour de la Martinique. Des thons de 20 à $68 \mathrm{~cm}$ de longueur à la fourche (LF) ont été capturés à la ligne de traîne de surface entre 0 et $10 \mathrm{~m}$ de profondeur. Les stries d'accroissement ont été comptées sur 76 otolithes en microscopie optique sur la partie externe des coupes transversales de la sagitta, du nucléus jusqu'à l'extrémité verticale de la coupe (coefficient de variations 2,4 \%). Afin de vérifier qu'il n'y avait pas de sous-estimation du nombre de stries, nous avons effectué un comptage, en microscopie électronique à balayage, pour 11 individus. La relation établie entre ces deux méthodes de comptage est linéaire avec un pente égale à 1,03 et $R^{2}=0,99$. La vitesse de croissance issue de l'analyse des otolithes a été comparée à celle estimée à partir de l'analyse en progression modale des distributions en fréquence de taille des débarquements sur une période de 2 mois. La corroboration entre les deux méthodes était bonne. Nous avons supposé que la formation des stries de croissance suivait un rythme journalier. Les paramètres de l'équation de croissance de von Bertalanffy pour les 2 sexes confondus sont : $L_{\infty}=71,4 \mathrm{~cm} \mathrm{LF}, k=0,002$ jour $^{-1}$ et $t_{0}=-80$ jours. Les résultats de cette étude n'indiquent pas que les DCP ancrés martiniquais puissent agir comme des pièges écologiques pour les thons noirs. Les jeunes thons noirs semblent au contraire quitter la proximité des DCP et entreprendre une migration trophique lorsqu'ils atteignent 7 à 8 mois. Ils ne reviendraient ensuite dans la zone des Petites Antilles qu'environ 8 mois plus tard, manifestement pour se reproduire.
\end{abstract}

\section{Introduction}

The blackfin tuna, Thunnus atlanticus (Lesson 1831), is a small-sized tuna which can be found in the Western

\footnotetext{
a Corresponding author: Mathieu.Doray@ifremer.fr
}

Atlantic approximately between latitudes $40^{\circ} \mathrm{N}$ and $25^{\circ} \mathrm{S}$. In Martinique and in most of the islands of the Lesser Antilles, blackfin tuna is a major target for small scale commercial fishermen (Doray et al. 2002a). Blackfin tuna is caught during daytime with sub-surface trolling lines, sometimes over seamounts 
but mostly around moored Fish Aggregating Devices (FADs). According to the sampling of partial landings conducted in Martinique by the French Research Institute for the Exploitation of the Sea (Ifremer), blackfin tuna is, in number of individuals, the main species caught around moored FADs. In fact, like other small-sized tunas, blackfin tuna is usually caught around FADs in order to be used as lived bait on single vertical drifting longlines that target adult blue marlin, Makaira nigricans (Lacepède 1802), and yellowfin tuna, Thunnus albacares (Bonnaterre 1788; Doray et al. 2002b).

Due to the growing importance of the domestic pelagic fisheries and because of the predictable development of moored FAD fisheries in the Lesser Antilles (FAO 2002), the knowledge of accurate population dynamics parameters, particularly those dealing with growth and age, is crucial in the short term to ensure a sustainable management of blackfin tuna stocks.

Growth features of adult blackfin tuna have been studied by some authors using several methods: modal progression (Beardsley and Richards 1970), tagging and scale reading (Idyll and DeSylva 1963), annular rings on vertebrae reading (Carles Martin 1975), annular marks in the first dorsal fin spine (Garcia Coll et al. 1984; Garcia and Bosch 1986), and comparison of results from dorsal fin spine, pectoral ray, anal fin spine, otolith and vertebra (Neilson et al. 1994). The results of these studies showing little consistency, we chose to study the growth of blackfin tuna caught around moored FADs in Martinique using otolithometry. The presence of a moored FAD fishery targeting blackfin tuna in Martinique suggested that the sampling of otoliths and statistical data for the study would be relatively straightforward. Moreover, because $75 \%$ of the T. atlanticus caught around moored FADs and sampled by Ifremer were juveniles (Doray et al. 2002b), interesting information should be gathered on the growth of juveniles tunas.

\section{Materials and methods}

All blackfin tunas, sampled in the present study, were caught with sub-surface trolling lines $(0-10 \mathrm{~m})$ near FADs moored around Martinique, from November, 1999 to January, 2001 at different landing sites around the island (Southern Atlantic coast and Northern Caribbean coast). Because of the reluctance of fishermen to mutilate their fish in order to extract otoliths, as previously reported for the area (Neilson et al. 1994), the head of the whole-fish had to be purchased most of the time.

\subsection{Otolith examination}

After fork length measurement ( $F L$ in $\mathrm{cm})$, only the largest otolith (sagittae) was dissected, either from freshly captured fish or from frozen specimens. Otoliths were removed from the otic cavity and stored dry. In the laboratory, sagitta were cleaned in household bleach, rinsed in distilled water, dried in alcohol and then embedded in a clear epoxy resin. Blocks containing sagitta were sectioned transversally on each side of the core with a Buehler Isomet ${ }^{\circledR}$ low speed diamond saw. The section was attached to a microscope slide with a Crystalbond ${ }^{\circledR}$ thermoplastic glue. The upper face was ground with a 1200 wet sand paper and polished with a series of different grit sizes of aluminium powder $(3 \mu \mathrm{m}, 1 \mu \mathrm{m}$ and $1 / 4 \mu \mathrm{m})$. When the core was close to the surface, the section was returned on the glass slide and the section was ground and polished again until the core was reached and a thin section of 75 to $100 \mu$ m maximum was obtained.

The surface of this thin section was partially decalcified with buffered EDTA (ethylene-diaminetetraacetic acid, $\mathrm{pH}=$ 7.2) to make the increments used to estimate the age more easily identifiable.

\subsection{Age determination and growth}

Microincrements were counted on these transverse sections under a light microscope (1000x) equipped with a MPL 100x dry lense. As for other tunas (Stéquert et al. 1996), the readings of increments were made on the external part of the transverse section along the ventral limb (Fig. 1). For each otolith, three independent counts were made at different times (without prior knowledge of the previous counts) and by three different readers. The mean, standard deviation and coefficient of variation $(C V)$ of age estimates were calculated for each fish. The coefficient of variation was calculated as $C V \%=100(S D / \bar{M})$, where $S D$ is the standard deviation and $\bar{M}$ is the mean of the three counts from each fish. The result of the reading is considered accurate enough if the $C V$ is lower than 5\% (Laine et al. 1991). An average $C V$ was also calculated for the whole sample, as the mean of the $C V$ s of all the fishes.

A relationship between otolith size and fish size (fork length) was described for further back calculations. Since transversal section was used for ageing, the length of the reading path $(C P)$ was considered as otolith size (Fig. 1c). In order to confirm counts made under light microscope, sections of sagittae from a sub-sample of 11 fish were prepared for examination under a scanning electron microscope (SEM).

We assumed that one increment on the transverse section of the otoliths corresponded to one day in order to build a von Bertalanffy growth model for blackfin tuna. We described the relationship between individual sizes $(F L$ in $\mathrm{cm})$ and ages ( $t$ in years which is supposed to be equal to the number of increments divided by 365). The equation of the model is $L_{t}=L_{\infty}\left[1-\exp \left(-k\left(t-t_{0}\right)\right)\right]\left(\right.$ Eq. (1)) where $L_{t}$ is fork length at age $t ; L_{\infty}$ the asymptotic fork length, $K$ the coefficient of growth and $t_{0}$ the theoretical age for $L=0$.

\subsection{Corroboration of age interpretation}

Methods for age corroboration cannot be used to validate the estimation of an absolute age but can be used to confirm the accuracies of an age estimate or that of a method. Monitoring of the progression of length frequency modes through time is one of the most basic of the length frequency analyses which is possible, and can be a reliable form of age corroboration in young, fast-growing fish (Campana 2001) such as juvenile 

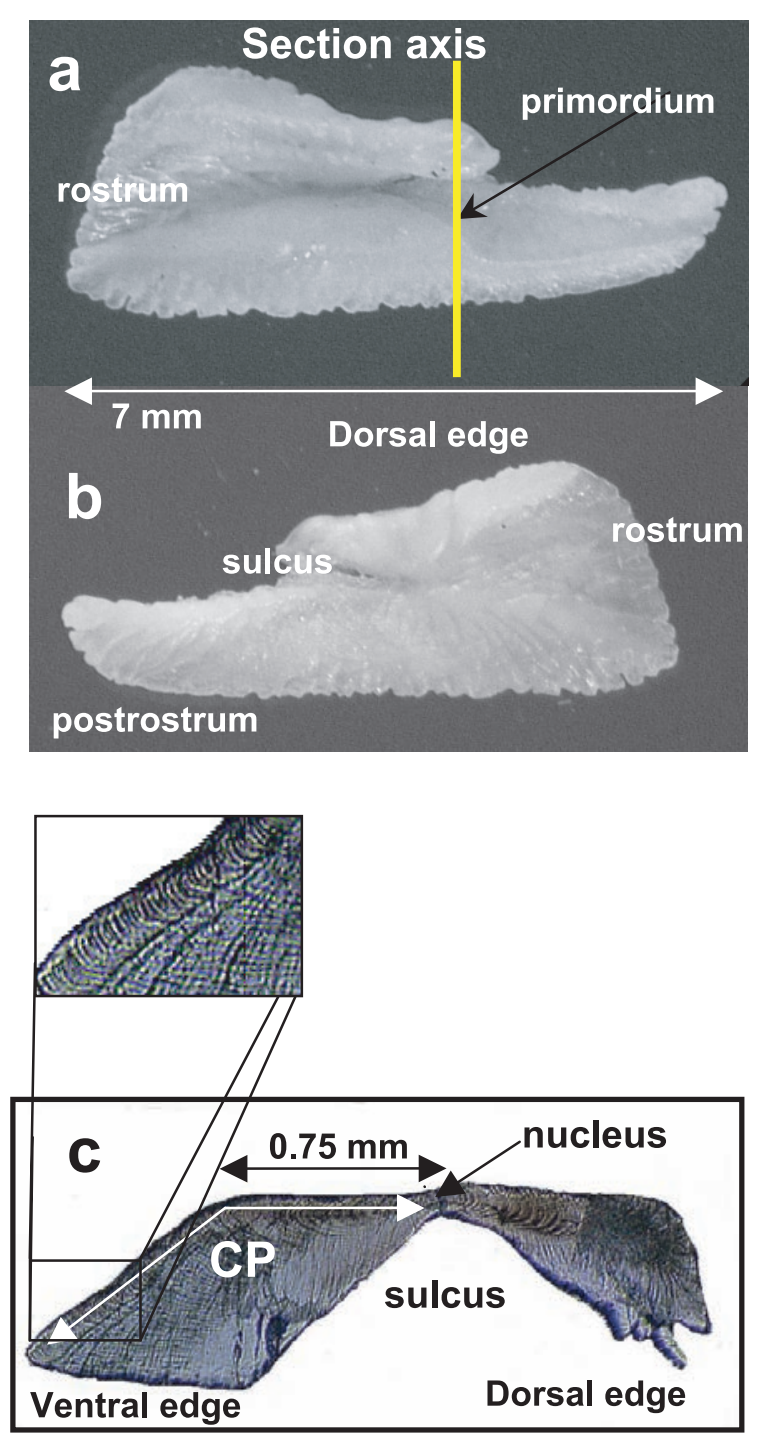

Fig. 1. Typical left blackfin tuna, Thunnus atlanticus, sagitta; (a) External face; (b) Internal face; (c) Transverse section from a left sagitta of a $35 \mathrm{~cm} F L, 200$ increments blackfin tuna, Thunnus atlanticus, with magnification of the growth increments on the counting path $(C P)$.

tunas. The corroboration occurs when the resulting growth estimate is compared to that of the age determination method (Campana 2001).

The distribution of monthly aggregated length frequency data of blackfin tuna caught around FADs and sampled from May, 1998 to May, 2002 showed little evidence of a shift of the smallest mode between July and September, in the FAD catches of the Northern Caribbean coast. Therefore, intensive sampling was conducted in order to measure as many blackfin tunas as possible during July and September, 2002 in the Northern Caribbean area.

The mean values $( \pm S D)$ of the modes in the size frequency distribution of the sample were estimated for July and September using the Bhattacharya's method, with the software FISAT issued from FAO-ICLARM (Gayanilo et al. 1995); $m_{1 i}$ is the mean value of the $i$ th mode in July and $m_{2 j}$ the value of
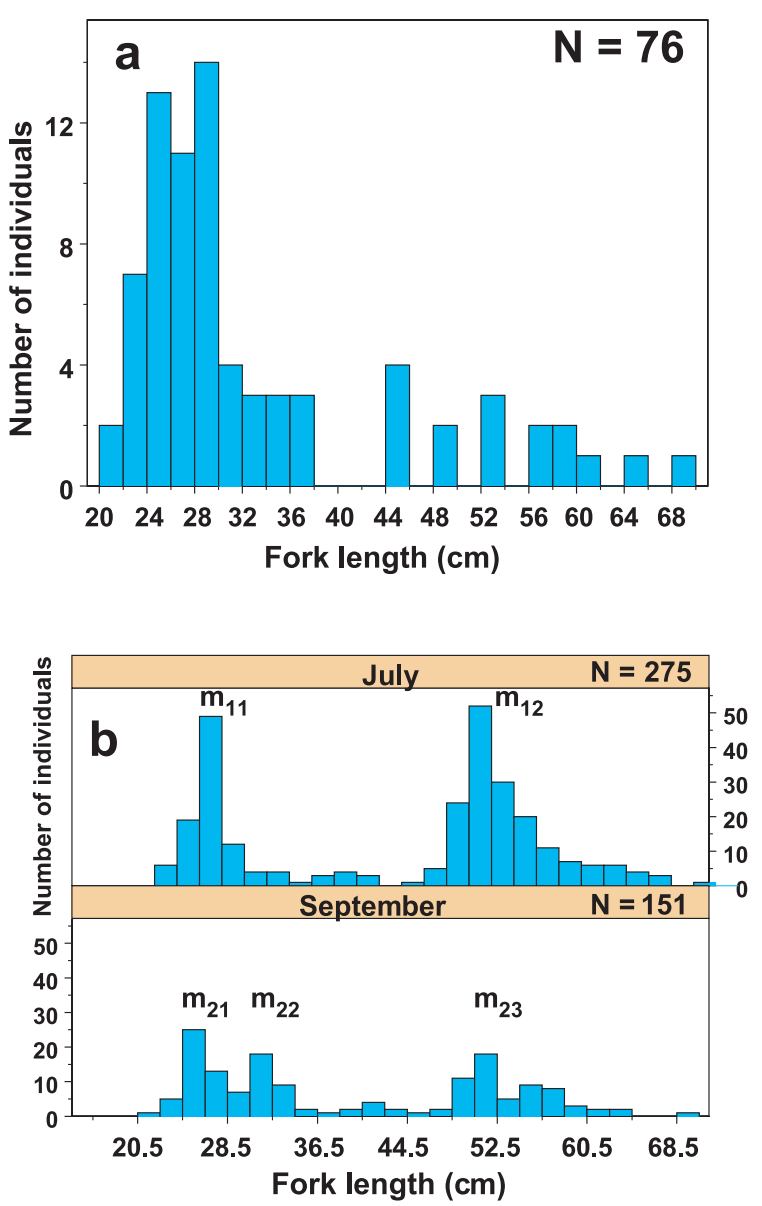

Fig. 2. Length frequency distribution of blackfin tuna (Thunnus atlanticus); (a) For which sagitta transverse sections were readable; (b) Samples obtained in July and September 2003, and used for corroboration of age interpretation (fork length classes $2 \mathrm{~cm}$ ).

the $j$ th mode in September. We assumed that each calculated mode $m_{1 i}$ and $m_{2 j}$ corresponded to a cohort and attributed each of them to their respective cohorts.

From equation (1), $\mathrm{t}$ value is determined as: $t=t_{0}-$ $\frac{1}{k} \log \frac{L_{\infty}-L_{t}}{L_{\infty}}$. We successively replaced $L_{t}$ by the $m_{1 i}$ values. We obtained the mean ages $t_{1 i}$ of the fishes for each of the cohorts for July. We calculated the theoretical values $m_{2 i}^{\prime}$ of the modes for each cohort " $i$ " in September, by replacing $t$ by $t_{2 i}=t_{1 i}+60$ in equation (1). Then, we compared, for each cohort " $i$ ", the theoretical $m_{2 i}^{\prime}$ to the experimental $m_{2 i}$ values, so as to corroborate the growth rates issued from otolith reading and from modal progression.

\section{Results}

All of the 76 fishes sampled had readable otoliths; they measured from 20 to $68 \mathrm{~cm}$ (Fig. 2a). The size distribution of the 426 fishes sampled for the modal progression study is presented (Fig. 2b).

The otoliths (sagitta) of blackfin tuna have essentially the same appearance as those from small yellowfin and bigeye tuna. After a confirmation at the microscopic level and because 


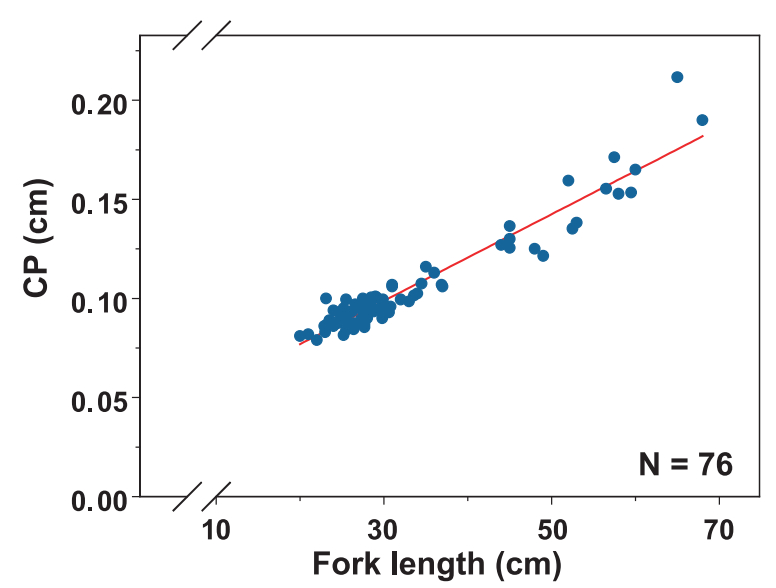

Fig. 3. Relationship between the length of the counting path $(C P)$ where counts were realized on the transverse section of black tuna, Thunnus atlanticus, sagitta and fish length $(F L)$.

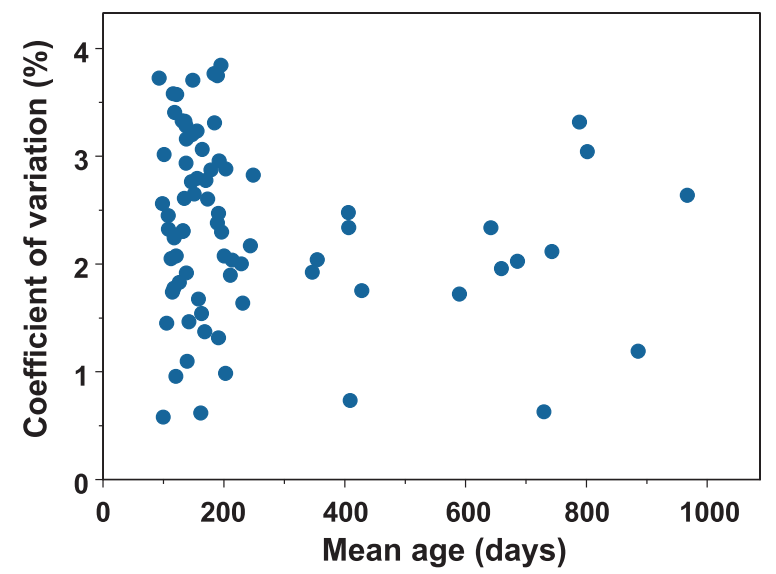

Fig. 4. Relationship between the coefficient of variation $(\mathrm{CV})$ and the mean of the age readings of each fish.

they also had the same structure, we considered that counting increments on the transverse section was the best way for the determination of age for the blackfin tuna.

\subsection{Age determination}

The calculated relationships between the length of the reading path $(C P$, in $\mathrm{cm})$ and the fork length $(F L, \mathrm{~cm})$ of the fishes is:

$$
C P=0.0022 F L+0.033 \text { with } R^{2}=0.918 \text { (Fig. 3). }
$$

The ages of the 76 blackfin tuna examined were estimated to range from 100 to 997 days with a coefficient of variation of the age estimates, $\overline{C V}=2.4 \%$ (Fig. 4).

The growth parameter estimates were calculated using a non linear regression procedure provided by the software STATISTICA ${ }^{\circledR}$. Age in days was used for calculations. The von Bertalanffy growth curve (VBGC) parameters were $L_{\infty}=71.4( \pm 9.2) \mathrm{cm}, k=0.002( \pm 0.001) \mathrm{day}^{-1}$ and $t_{0}=$ $-80( \pm 47)$ days with $R^{2}=0.99$ (Fig. 5).

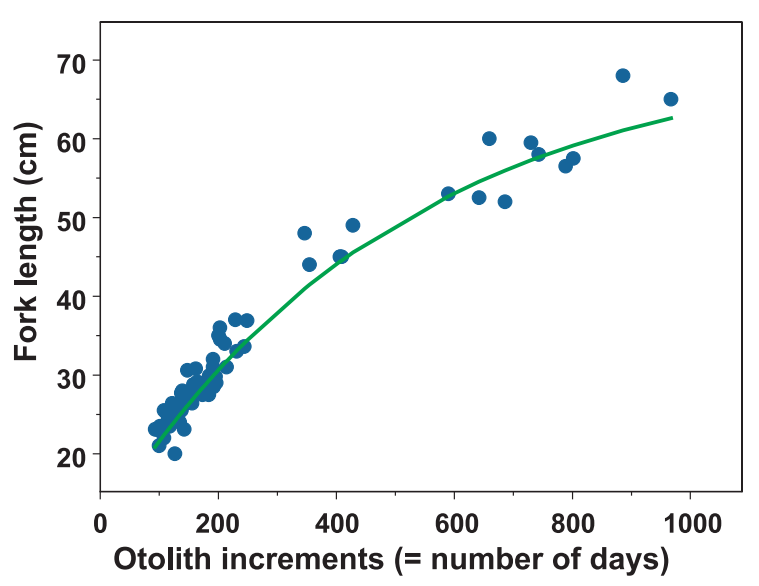

Fig. 5. Age estimate for blackfin tuna, Thunnus atlanticus, and fitted von Bertalanffy growth curve ( $N=76$ individuals).

After determination of age under light microscope, $11 \mathrm{sec}$ tions of otoliths were prepared for observation and reading under scanning electron microscope. The relationship between the ages determined by both methods is: $N_{\text {opt }}=1.03 N_{\text {sem }}-$ 3.12 with $R^{2}=0.99$, where $N_{\text {opt }}$ is number of increments under light microscope and $N_{\text {sem }}$ number of increments under scanning electron microscope. Since the slope of this linear relationship is not significantly different from 1 , we can consider that light microscope does not underestimate age.

\subsection{Corroboration of age interpretation}

A total of 275 and 151 blackfin tunas were measured in July, 2002 and September, 2002 respectively.

Two predominant modal classes $\left(m_{11}\right.$ and $\left.m_{12}\right)$ were identified in July (Fig. 2b). These modes although still present in September, were less important. A new mode of recruits appeared in September $\left(m_{21}\right)$, becoming the main component of the distribution; this mode probably originated from a truncated mode of juveniles $(F L \leq 25 \mathrm{~cm})$, which was visible in July. Hence, young tunas appear never to be recruited into the moored FAD fishery at sizes less than $20 \mathrm{~cm}$ as a result of the selectivity of the trolling lines. In September, the second mode $\left(m_{22}\right)$ could be considered as corresponding to the same cohort as the mode $\left(m_{11}\right)$ observed in July. Similarly in September, the last mode $\left(m_{23}\right)$ originates from the mode $\left(m_{12}\right)$ observed in July.

The mean values $( \pm S D)$ of the modes, the calculated $t_{i}$ values and the $m_{2 i}^{\prime}$ values are presented in Table 1 for the cohorts of July and September.

As the calculated modes were very close to the experimental modes $\left(m_{21}=32\right.$ and $m_{22}^{\prime}=32 \mathrm{~cm} ; m_{23}=53$ and $m_{23}^{\prime}=54 \mathrm{~cm}$ ), we considered that the growth rate derived from modal analysis was very comparable to the growth rate derived from otolith analysis. For the time period considered, we concluded that the corroboration and then the accuracy of the otolith aging method were good. 
Table 1. Results of the modal analysis from Bhattacharya's method (FISAT-FAO-ICLARM) concerning the sampling experiments realized between July and September 2002.

\begin{tabular}{ccc}
\hline $\begin{array}{c}\text { Experimental mode } \pm S D \\
(\mathrm{~cm})\end{array}$ & $\begin{array}{c}t_{i} \text { values } \\
(\text { days })\end{array}$ & $\begin{array}{c}\text { Calculated mode } \\
(\mathrm{cm})\end{array}$ \\
\hline$m_{11}=26 \pm 1$ & $t_{11}=137$ & \\
$m_{22}=32 \pm 1$ & $t_{12}=197$ & $m_{21}^{\prime}=32$ \\
\hline$m_{12}=51 \pm 2$ & $t_{21}=505$ & \\
$m_{23}=53 \pm 2$ & $t_{22}=565$ & $m_{22}^{\prime}=54$ \\
\hline
\end{tabular}

\section{Discussion}

The small scale moored FAD fisheries in Martinique is characterised by irregular catches landed at 131 landing sites scattered around the island (Gobert 1989). This context as well as a reduced sampling capacity have hindered the implementation of a classical random sampling plan.

The majority of the fishes in our sample being juveniles $(79 \%)$, we were not able to distinguish between sexes. Garcia Coll et al. (1984) found a significant difference in growth rate between male and female blackfin tuna in Cuba whereas Garcia et al. (1986) found none in the same area.

$L_{\infty}$ obtained in the present study is nearly $30 \%$ less than the maximum length ever recorded for a blackfin tuna $(100 \mathrm{~cm})$ (Collette and Nauen 1983), which, according to Fishbase, is a consistent result (Froese and Pauly 2003). The biggest fish in our sample was $68 \mathrm{~cm}$ long and would be 3 years old according to our VBGC. The biggest blackfin tuna sampled in Martinique since May, 1998 was $81 \mathrm{~cm} F L$ long. To our knowledge, no data is available on the longevity of blackfin tuna.

The $k$ factor is the highest mentioned in the literature and the time at length zero is far lower than in other studies (Table 2). This result suggests that the blackfin tuna could have a higher daily growth at early stages than previously assumed. Our sample is characterised by a high number of small fishes and may better reflects the growth of juvenile blackfin tunas. In fact, sub-surface trolling lines mainly allow the catch of small juvenile blackfin tunas. During echosounding surveys around moored FADs in Martinique, large aggregations of adult blackfin tunas were observed below the depth layers targeted by surface trolling lines (Doray, unpublished data). Adult fish are however poorly represented in our sample (16 individuals).

The growth rings of 12 blackfin tuna otoliths from $\mathrm{St}$ Vincent, another island of the Lesser Antilles were previously studied (Neilson et al. 1994). The age estimations given in that study were very different from our results: being on average 3.3 years older than those issued from otolith reading from Martinique.
Migration is often pronounced in young fish and this hinders the use of sampled modal progression for daily age validation (Campana 2001). Hence, we were only able to follow what we supposed was an age group during 2 months, whilst we should have performed a modal progression analysis over a year in order to achieve an absolute age validation (Campana 2001).

The small number of blackfin tuna between 35 and $48 \mathrm{~cm}$ $F L$ observed in Martinique may be the result of a "trophic migration" (Taquet et al. 2000). According to our VBGC, the blackfin tunas could leave the vicinity of Martinique when they reach a size of about $32 \mathrm{~cm}$ i.e. at the age of 7 months. They could return to the island about 8 months later, at the age of 1.5 year $(52 \mathrm{~cm} F L)$ apparently to breeding.

The minimum size of first maturity for the blackfin tuna near Cuba is $39 \mathrm{~cm}$ in fork length (García-Cagide et al. 1994). According to Taquet et al. (2000), because of the "observation, during May and June, of numerous mature males and females around FADs, there probably is a blackfin tuna breeding ground in the Lesser Antilles". Thunnus atlanticus is assumed to spawn between April and September in the Caribbean, and between March and October in the Gulf of Mexico (Battaglia 1993). The smallest length mode for the catches in Martinique $(26 \mathrm{~cm})$ is observed between August and November. According to our VBGC, those fishes would be between 2 and 4 months old. The juveniles of the year would hence be born between March and October, which is within the spawning period given by Battaglia (1993).

\section{Conclusion}

As mentioned by Fréon and Dagorn (2000), "most of the studies on the behaviour of fish under floating objects have been conducted on fish associated with anchored FADs, because of several factors such as the major role of FADs in the development of some artisanal fisheries, and because of their locations in accessible coastal areas". The results presented here confirm that moored FADs also provide opportunities to study the biology of the large pelagic species.

The corroboration method used in this study provided good results over two months. The daily deposition rate of growth increments of blackfin tuna should, however, be validated with methods that have successfully been applied to other species of tuna: for example tag-return experiments (e.g. Hearn and Polacheck 2003) or otolith chemical marking and rearing (e.g. Tanabe et al. 2003). The growth rate of adult blackfin tuna should also be thoroughly studied to get an accurate growth model for both sexes and across the age range of interest.

Table 2. Comparison of the von Bertalanffy equation parameters for blackfin tuna.

\begin{tabular}{|c|c|c|c|c|c|c|c|}
\hline Reference & $\begin{array}{c}\text { Geographical } \\
\text { area }\end{array}$ & $L \infty(\mathrm{cm})$ & $\begin{array}{c}k \\
\left(10^{-6} \mathrm{yr}^{-1}\right)\end{array}$ & $t_{0}(\mathrm{yr})$ & Method & $\begin{array}{l}\text { Mean (Size } \\
\text { Range) }(\mathrm{cm})\end{array}$ & $\mathrm{N}$ \\
\hline This paper & Western coast of Martinique & 71.4 & 5.5 & -0.22 & Otoliths & $33(20-68)$ & 76 \\
\hline Carles Martin (1975) & Western part of Cuba & 78.5 & 2.5 & -1.57 & Vertebrae & NA (26-74) & NA \\
\hline Garcia et al. (1984) & Southwestern part of Cuba & 55.9 & 2.7 & -1.77 & First dorsal fin spine & 46 (NA) & 77 \\
\hline Garcia and Bosh (1986) & Northeastern part of Cuba & 59.8 & 2.5 & -4.42 & First dorsal fin spine & 53.8 (NA) & 416 \\
\hline
\end{tabular}


The fact that we observed progression of the modes in the length frequency distribution of catches from moored FADs between July and September, 2002 and more generally in the cumulated monthly data from 1998 to 2002, indicates that juvenile and adult blackfin tuna, observed in July, must have remained associated with moored FADs around Martinique for at least 2 months. We did not find convincing evidence of a longer association of those tunas with the moored FADs in our dataset and rather, blackfin tuna seem to leave when they reach the age of 7 to 8 months. According to our growth and age model and to the length structure of the catches, there is no evidence that the moored FADs act as an "ecological trap" (Marsac et al. 2000) in Martinique.

Acknowledgements. We would like to thank E. Morize and L. Marec for their technical assistance in the laboratory and A. Lagin, for his assistance during the sampling work. The authors are also very grateful to Corinne S. Martin who kindly revised the English of the text.

\section{References}

Battaglia A., 1993, Les grands poissons pélagiques à la Martinique et en région Caraïbe. Biologie et pêche. Ifremer, Rapp. DRV $\mathrm{N}^{\circ}$ 93/027.

Beardsley G.L., Richards W.J., 1970, Size, seasonal abundance, and length-weight relation of some scombrid fishes from Southeast Florida. U.S. Fish Wildl. Serv. Spec. Sci. Rep. Fish N 595.

Campana S.E., 2001, Accuracy, precision and quality control in age determination, including a review of the use and abuse of age validation methods. J. Fish Biol. 59, 197-242.

Carles Martin C.A., 1975, Edad y crecimiento del bonito (Katsuwonus pelamis) y la albacora (Thunnus atlanticus) en la parte occidental de Cuba. Rev. Invest. Cent. Invest. Pesq. Inst. Nac. Pesca (Cuba) 1, 203-254.

Collette B.B., Nauen C.E., 1983, FAO species catalogue. Scombrids of the world. An annotated and illustrated catalogue of tunas, mackerels, bonitos and related species known to date. FAO Fish. Synop. 125, 2.

Doray M., Reynal L., Carpentier A., 2002a, Les pêcheries de poissons pélagiques hauturiers aux Petites Antilles en 2001. Supplement to the Report of the First meeting of the WECAFC Ad-hoc Working Group on the Development of Sustainable Moored Fish Aggregating Device Fishing in the Lesser Antilles, FAO Fish. Rep. 683.

Doray M., Reynal L., Carpentier A., Lagin A., 2002b, Le développement de la pêche associée aux DCP ancrés en Martinique. Supplement to the report of the First meeting of the WECAFC Ad-hoc Working Group on the Development of Sustainable Moored Fish Aggregating Device Fishing in the Lesser Antilles. FAO Fish. Rep. 683.

FAO 2002, Report of the First meeting of the WECAFC Ad-hoc Working Group on the Development of Sustainable Moored Fish
Aggregating Device Fishing in the Lesser Antilles. FAO Fish. Rep. 683.

Fréon P., Dagorn L., 2000, Review of fish associative behaviour: toward a generalisation of the meeting point analysis. Rev. Fish Biol. Fish. 10, 183-207.

Froese R., Pauly D., 2003, Fishbase. World Wide Web electronic publication. www. fishbase.org, version 12 Nov. 2003

Garcia C.I., Bosch M.A., 1986, Determinacion de la edad y crecimiento del bonito, Katsuwonus pelamis y la albacora, Thunnus atlanticus en la region nororiental de Cuba. Rev. Invest. Mar. 7, 47-54.

Garcia Coll I., Alvarez-Lajonchere L.S., Noyola Ugalde J.I., 1984, Determinacion de la edad y el crecimiento del bonito Katsuwonus pelamis (Linnaeus) y la albacora Thunnus atlanticus (Lesson) en la region suroccidental de Cuba en el ano 1979. Rev. Invest. Mar. 5, 95-126.

García-Cagide A., Claro R., Koshelev B.V., 1994, Reproducción. In: Claro R. (Ed.) Ecología de los peces marinos de Cuba. Instituto de Oceanologia Academia de Ciencias de Cuba and Centro de Investigaciones de Quintana Roo, CIQRO, Mexico.

Gayanilo F.C.J., Sparre P., Pauly D., 1995, The FAO-ICLARM stock assessment tools (FiSAT) user's guide. FAO Computerized Information Series (Fisheries) N ${ }^{\circ} 8$, Rome, FAO.

Gobert B., 1989, Effort de pêche et production des pêcheries artisanales martiniquaises. Doc. Sci. ORSTOM, Pôle Caraïbe 22, 98.

Hearn W.S., Polacheck T., 2003, Estimating long-term growth-rate changes of southern bluefin tuna (Thunnus maccoyii) from two periods of tag-return data. Fish. Bull. 101, 58-74.

Idyll C.P., DeSylva D.P., 1963, Synopsis of biological data on the blackfin tuna, Thunnus atlanticus (Lesson, 1830) (Western Atlantic). FAO Fish. Rep. 6, 761-770.

Laine A.O., Momot W.T., Ryan P., 1991, Accuracy of using scales and cleithra for aging northern pike from an oligotrophic Ontario Lake. N. Am. J. Fish. Manage. 11, 220-225.

Marsac F., Fonteneau A., Ménard F., 2000, Drifting FADs used in tuna fisheries: An ecological trap? In: Le Gall J.Y., Cayré P. and Taquet M. (Eds.), Pêche thonière et dispositifs de concentration de poissons. Ifremer, Actes Colloques 28, 537-552.

Neilson J.D., Manickhand-Heileman S., Singh-Renton S., 1994, Assessment of hard parts of Blackfin Tuna (Thunnus atlanticus) for determining age and growth. Standing Committee on Research and Statistics, Collect. Vol. Sci. Pap. ICCAT Madrid.

Stequert B., Panfili J., Dean J.M., 1996, Age and growth of yellowfin tuna, Thunnus albacares, from the western Indian Ocean, based on otolith microstructure. Fish. Bull. 94, 124-134.

Tanabe T., Kayama S., Ogura M., 2003, Precise age determination of young to adult skipjack tuna (Katsuwonus pelamis) with validation of otolith daily increment in 16th Meet. of the standing Committee on Tuna and Bill Fishes, SCT B16 working paper $\mathrm{N}^{\circ}$ SKJ-8 Noumea (New Caledonia), Secretariat of the Pacific Community.

Taquet M., Reynal M., Laurans M., Lagin A., 2000. Blackfin tuna (Thunnus atlanticus) fishing around FADs in Martinique (French West Indies). Aquat. Living Resour. 13, 259-262. 